\section{Industry 4.0 and \\ Current Competencies}

\section{Eva Beke}

Óbuda University, Doctoral School on Safety and Security Sciences, Hungary beke.eva@phd.uni-obuda.hu

\section{Richard Horvath}

Óbuda University, Donat Banki Faculty of Mechanical and Safety Engineering, Hungary

horvath.richard@.uni-obuda.hu

\section{Katalin Takacs-Gyorgy}

Óbuda University, Karoly Keleti Faculty of Business and Management, Hungary takacsnegyorgy.katalin@uni-obuda.hu

\begin{abstract}
There is a growing gap between higher education systems and the needs and demands of the labor market. Many of today's students will work at jobs that just have emerged or do not even exist yet. The "newcomers" will need both digital and social-emotional skills in the coming years. These new competencies will make the new generation of employees' company goals. This article presents the results of the recent research about modern-day competencies to evaluate what exactly relevant companies' expectations are, how students see their knowledge and value in future workplaces, and how academia is coping with this new demand. For this analysis, I have conducted deep interviews with applicable entities, namely companies from the car industry and from the field of security industries (cyber security, integrated camera surveillance, financial security) to see how Industry 4.0 shapes the competencies they expect from our students entering to the job market. Engineering students - by questionnaire -were also interviewed at the Óbuda University, to examine their views about the skills gained at the university and how these competencies helping them to apply for the right position in the job market. Although the competence list showed similarities in the expected skill sets, the order of them differs. While most companies are aiming to hire team players with creative problem solving and those are capable and willing to accept changes, the students' observations showed that technical skills, expertise, and problem solving are the most important competencies for future employment. Based on all participants' answers and additional research, we aim to involve international companies to take part in our higher education system more thoroughly either by widening the practical in-site education or by inviting them to our university for lecturing future engineers. Furthermore, new courses are introduced at our university, such as information security, humanitarian response management, rehabilitation environmental planning engineering or ergonomics and human factors specialization.
\end{abstract}

Keywords: competencies for industry 4.0, university education, future curricula, Education 4.0
ORIGINAL SCIENTIFIC PAPER

RECEIVED: MARCH 2020

REVISED: OCTOBER 2020

ACCEPTED: OCTOBER 2020

DOI: 10.2478/ngoe-2020-0024

UDK: $338.45: 37.011 .2: 378$

JEL: M51, J44, J24

Citation: Beke, E., Horvath, R., \& Takacsne, G. K. (2020). Industry 4.0 and Current Competencies. Naše gospodarstvo/Our Economy, 66(4), 63-70. DOI: 10.2478/ngoe-2020-0024

\section{NG OE}

NAŠE GOSPODARSTVO OUR ECONOMY

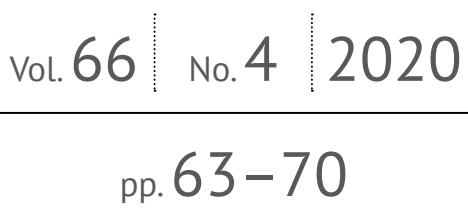




\section{Introduction}

The first three industrial revolutions were determined by special technological advancements, which enabled development by leaps and bounds - the steam engine, electricity, and computers. In the 21st century, we have been witnessing the fourth industrial revolution, characterized by the development of independent technologies, each with world-changing potential. From artificial intelligence to genetic engineering, virtual reality, and digital currencies (Cséfalvay, 2017). These advances have brought substantial benefits to society (Beke, 2018). However, they also pose major challenges. The transformation in Industry 4.0 is fundamentally different from the former periods, both in terms of speed and magnitude of change. As new technologies arise from many areas, such as sensor driven manufacturing and agriculture, robotized operation systems or artificial intelligence based autonomous flying, security and surveillance, healthcare and medical imaging analysis or warehousing and logistic supply chain, it is harder than ever to foresee where the opportunities are with newly acquired skills (Andrasko \& Baracskai, 2020). We are in the middle of an accelerated industrial, social, and economic transformation that has brought many remarkable advances and unprecedented access to data and the Internet of Things. These innovations and technologies have impacted almost all segments of our economy, as well as a wide range of occupations including cybersecurity, communication, transportation, critical infrastructure, and manufacturing, naming only a few (Aryal et al., 2019). This transformation of technology heralded greater mobility and logistics, new trade routes, rising energy needs, and the development of renewable energy supply, shifts in global economic power, and new markets. These trends have further influenced social and cultural behavior (Oosthuizen, 2019), such as ecological awareness, smart technologies and a new way of approaching education and obtaining knowledge (Bevan et al., 2018). Education 4.0 is a prime example and a great response to all global changes to enhance employability and skills needed in digitalized smart manufacturing, production or in security industries.

If academia and higher education want to keep up with all these changes, the recent educational system needs to be reshaped and Education 4.0 or some recommendations of it must be introduced, too. Many questions need to be answered. First what would be the best curricula today that will provide adequate knowledge for tomorrow's marketplace (Szalavetz, 2018) or how should be educated tomorrow's citizens and leaders to unlock this potential (Bencsik et al., 2016). Further to the point, what will jobs be like in the future when so many of them will be lost through technical improvements or who will monitor the use of big data and the implicit distortion of data, and its consequences for a fair society. Some of these changes are already here, so universities need to prepare rather carefully to meet these demands (Michalos et al., 2015).

The research is structured around these questions by asking both students and the relevant business entities in different ways: we have conducted deep qualitative interviews with the industry representatives and have students complete a questionnaire that will be analyzed quantitatively.

\section{Theoretical Background}

To serve society and industry for a better future, academic education must regain what it has lost: to teach the duality of science and humanities together in connection with the economy, industry, and social environment expectations. For centuries, knowledge based on ancient science and humanities, it was the basis of culture, the knowledge of Greek and Latin languages, ancient mythologies, literary, philosophical, and historical works, mathematical theories and sea navigation, and also Roman law was essential in higher education. Later in Europe, and within the scope of Western education, this was supplemented by the knowledge of the Bible and the Christian tradition. The first universities and schools were established to mediate this professional tradition. The Enlightenment twisted all of these, although it did not fundamentally change the notion of valid knowledge, however it defined all-important philosophical issues in relation to, derived from, or opposed to the ancient and Christian tradition. This critical relationship with tradition did not mean a final break with old education systems and curricula and placing the importance solely of the spirit of innovation in focus. It did not abolish the concept of tradition, but gradually transformed it. However, in the "new age", inherited patterns of knowledge have become less and less successful, and in the changed circumstances, success has already been ensured if one has been able to make independent decisions, able to accept the changes and/or even choose unusual paths. As a result, by the second half of the 20th century, Latin culture was not a basic criterion, rather the practical and scientific knowledge, as they became part of literacy among professionals with higher education. This knowledge serves a dual purpose: on the one hand, to achieve better prosperity, to serve industry, technology, constantly evolving production, technological and economic competition, and on the other hand, the importance of independent decision-making processes that underpins the self-conscious, secure and legitimate citizenship. Understandably, with the rapid development and consolidation of disciplines, it makes no sense to teach only within the older framework; especially those subjects that most likely will disappear soon, as lessens those people are interested in to study the science of classi- 
cal philology, library, folk culture or literature theories, even though in the future, more than just technical and IT knowledge will be needed. Even in a technologically driven world, the study of humanities is essential to address and to resolve the great challenges of working together with robots, changing routines in manufacturing or in the transport system (Benesova \& Tupa 2017). Emotional intelligence, people skills, active listening, and communication skills are appreciated more and more by employers while those technical skills which can be done by robots devalued. The distinction between human sciences and technology carries the risk of seeing technology as the ultimate solution, not as a means of improving human existence. Without the understanding of the nature and the relationship between technology and human interaction, the technology does not reflect human needs, but rather a robotized environment (Mulder, 2014).

To prepare for the talents needed in the digital economy and to teach new competencies, education must adapt as the demand for IT and for social skills to grow and develop (Schwab, 2017).

"The Education 4.0 initiative aims to create a common agenda to transform education systems to ensure future-readiness among the next generation of talent:

- Creating a global framework for shifting the content of learning and the mechanisms by which it is delivered to more closely mirror the needs of the future.

- Shaping a model to reskill and upskill teachers as the key stakeholder whose adaptation has a multiplier effect on the next generation.

- Highlighting new policy pathways to enable Education 4.0.

- Building a marketplace for connectivity, collaboration and learning between schools and schooling systems across the world” (WEF, 2016).
According to a survey by the World Economic Forum (WEF, 2016), the competencies that were essential in 2015 will change by 2020, as shown in Table 1 .

\section{Data and Methodology}

\section{Deep interviews with relevant companies}

To answer the questions raised for this research, we looked for companies that either already has adopted the transformations of Industry 4.0 or related to the studies of our students at the mechanical engineering or security engineering faculties. The international car industry, including those that produce car parts or develop new production methods, was chosen to match better our mechanical engineering students' studies and interests from the academic side. We interviewed multinational companies and local SMEs to see and evaluate their competence preferences. We conducted interviews either in person or by telephone. We compiled a questionnaire that focused on current job market issues and worked to produce insights into the compact of future employees, their needs, and career paths (Simic \& Nedelko, 2019). We also considered it important to ask industry representatives, in most cases executives or hiring professionals, what suggestions they would make for a fruitful collaboration between industry and academia and asked how they would restructure the education system accordingly.

The exploratory research with questionnaires aimed to gather more detailed and deeper knowledge-based information on the opinion of the interviewees at a relatively

Table 1. Competences' order changes between 2015 - 2020

\begin{tabular}{ll}
\hline 1. Competences' order in 2015 & Competences' order in 2020 \\
\hline 2. Complex Problem Solving & 1. Complex Problem Solving \\
\hline 3. Critical Thinking & 2. Coordinating with Others \\
\hline 4. Creativity & 3. People Management \\
\hline 5. People Management & 4. Critical Thinking \\
\hline 6. Coordinating with Others & 5. Negotiation \\
\hline 7. Emotional Intelligence & 6. Quality Control \\
\hline 8. Judgment and Decision-Making & 7. Service Orientation \\
\hline 9. Service Orientation & 8. Judgment and Decision Making \\
\hline 10. Negotiation & 9. Active Listening \\
\hline 11. Cognitive Flexibility & 10. Creativity \\
\hline
\end{tabular}


small sample size. We based our research on the topic of industry-expected competencies. We asked the representatives of some of the most influential and innovative car companies in Hungary to evaluate and compare the answers on both sides: student studies and knowledge and the car industry's response. Participants represented two groups based on their workplace profile: one was for those who were developing their companies in the spirit of Industry 4.0, with robotics, innovation, process organization, modernization, or the acquisition of the most innovative production lines (Hood \& Nanda 2018). The two other companies consulted were insurance companies that dealt with different parts of security insurance and liability, such as hacking, data protection, which we considered part of security science. The first group, related to the car industry, was the most relevant industrial sector for the students who participated in our survey, as most of them wish to work there either in the production of parts or in the field of design. Respondents included four international companies and two medium-sized Hungarian SMEs (Birkner et al., 2018) All respondents received the same questionnaire, and the answers were anonymous, indicating only the position occupied at the company.

\section{Student survey}

We also compiled a student questionnaire to expand and specify the responses of the competences' order. We made a quantitative field survey with BSc students of engineering at the Óbuda University in 2019. The number of completed and evaluative questionnaires was 96 out of 110 . Though the survey was not considered to be fully representative, the results and the tendencies provide excellent insights into how to adopt a curriculum that was appropriate to the Industry 4 future. The average time for completion of the questionnaire was 20 minutes, so participants had enough time to decide which options would best suit them. All students received the same questionnaire, so the results were comparable. In-person, random interviews with some students revealed that many of them already had valid industry experience, whether through internships, part-time employment, or contract work, which made the responses even more valuable. We evaluated the answers by using a Pareto diagram because this method proved to be the most suitable for summarizing and interpreting the data.

\section{Results}

One of the questions addressed to ten representatives was about those competencies, which the company sought when selecting a candidate. As Figure 1 shows, the replies are grouped as follows: Two of the respondents were very specific about wanting to know the students' knowledge of "mechanical engineering," while another two considered "effective problem-solving" as more important than purely technical skills. Half of the respondents, a total of three companies, said that "teamwork," "creativity," and "change management" had a decisive influence on their choices, as they have on-site training and were willing to further coach the right employee. Two of them stated that it was important for the candidates to have the drive for the work, especially that which drives innovation and better solutions for these companies. One respondent indicated that "mental balance," “adaptability,” and “critical thinking” played an important role in whom they would hire. Adaptability was emphasized mainly because the rapidly changing environment requires it. Given the differences between generations, one respondent considered "mixedage" important, meaning that more than one generation should be working together at all phase of production, what would give a more dynamic working environment with the option to learn from each other, while another respondent considered “conflict-solving” crucial in an Industry 4.0-based production line. Two professionals noted that common projects between academia and industry would be beneficial for both sides, and two others mentioned that some of the young applicants' lack of communication, presentation skills, and self-awareness was poor, although these competencies play an important role in teamwork. One multinational company's representative signaled that they would invite and educate university lecturers on-site to see the newest technology developments - those driven by Industry 4.0 - and have a series of lectures for those in their last semester at the university and would like to work in the car industry. Presently, the university curriculum does not keep up with the newest technological advancements, although plenty of new subjects were incorporated in academic studies, some even for post-graduates: eg. biometric studies, cyber-security and project management, or information security and occupational rehabilitation human and technical consultant continuing studies. Further enhancements in education would result in better-suited and more prepared employees. One suggestion offered by a multinational company was to use case studies for students to learn how to develop a project, or how important self-development and personal drive are in teamwork. All these recommendations can be implemented in university curricula. At the same time, universities can offer special research groups, analyses, or marketing advice for companies in need.

The results of the student surveys can be seen in Figure 2. Twenty-two percent of the respondents considered problem-solving critical, while $19.52 \%$ sought expertise in the related field, and 9.93\% found technical/IT skills important. The first three most important attributes represented 
Figure 1. Competence order expected by companies

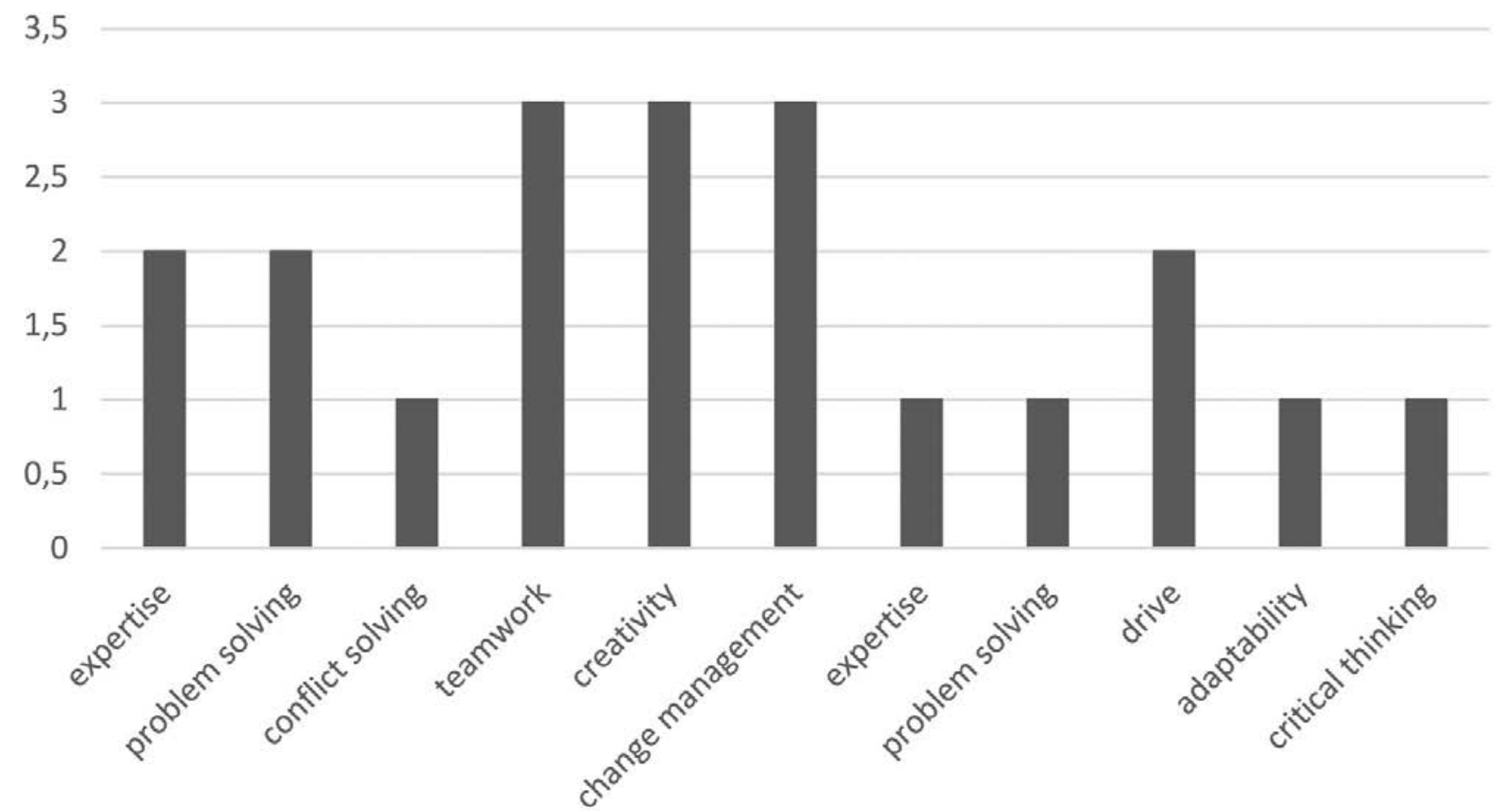

$52.05 \%$ of the total responses, so more than half of the students considered these three competencies as essential skills to succeed in their future workplaces. Surprisingly, communication skills rank fourth, while teamwork and creativity placed only sixth and seventh places, indicating that those competencies for engineering students are less important than those closely related to the industry. Foreign language skills (English or German have been the two most chosen languages in Hungary) had a surprisingly low ranking, even though at most international companies the working language is not Hungarian, but English or, in some cases, German. So, speaking and understanding these languages can still be a decisive factor in hiring (Gunnarsson, 2014). To support this demand, we introduced subjects taught in English or German and made some of them obligatory. We also encouraged foreign internships not only to widen industry experience but also to develop a solid knowledge of these languages (Portera \& Grant 2017). Decision-making and consequent responsibility was not a highly desirable skill on the students' list, as they have only entered the job market. Those skills will weigh more in later years when they have more experience and are in higher positions.

Comparing these data with the responses from companies, the first three places are not shared in common, as half of the surveyed corporate representatives indicated teamwork, creativity, and change management as the most sought-after skills (Schwartz et al., 2019). Self-knowledge is a skill that would facilitate better orientation in the world and later in the profession, was on less than $10 \%$ of the students' list as a valuable skill. If we compare our results with both the companies and the students to larger international research with a representative number of samples and taking into account the entire list of competencies from these surveys, we can say that our results were comparable to international trends and validated our research. The further development of these competencies has importance, as Industry 4.0 next generation is already here with artificial intelligence (AI) collecting an enormous amount of data in real-time. The use of AI also requires better teamwork to have a better insight into the production process and flexibility in problem-solving to avoid any operational inefficiency (Byström et al., 2017). Understandably, creativity in technical solutions and the ability to accept changes are also important for future candidates (Wagenaar, 2014). Using cloud computing allows data to be accessed anytime, anywhere, which is also critical in manufacturing. Furthermore, in the global market, proper distribution and logistics are essential, as are data exchange, information sharing, and consequent data management and communication skills (Miller \& Marsh 2014). With a new generation of robots, there is a new demand for people to operate them (Črešnar \& Jevšenak, 2019). Therefore, the above-mentioned skills and expected competencies not picked randomly, but rather selected by experienced company representatives who all work in related fields and face day-to-day operational, technological issues (Mohle, 2012). 
Figure 2. Competence order by students' survey

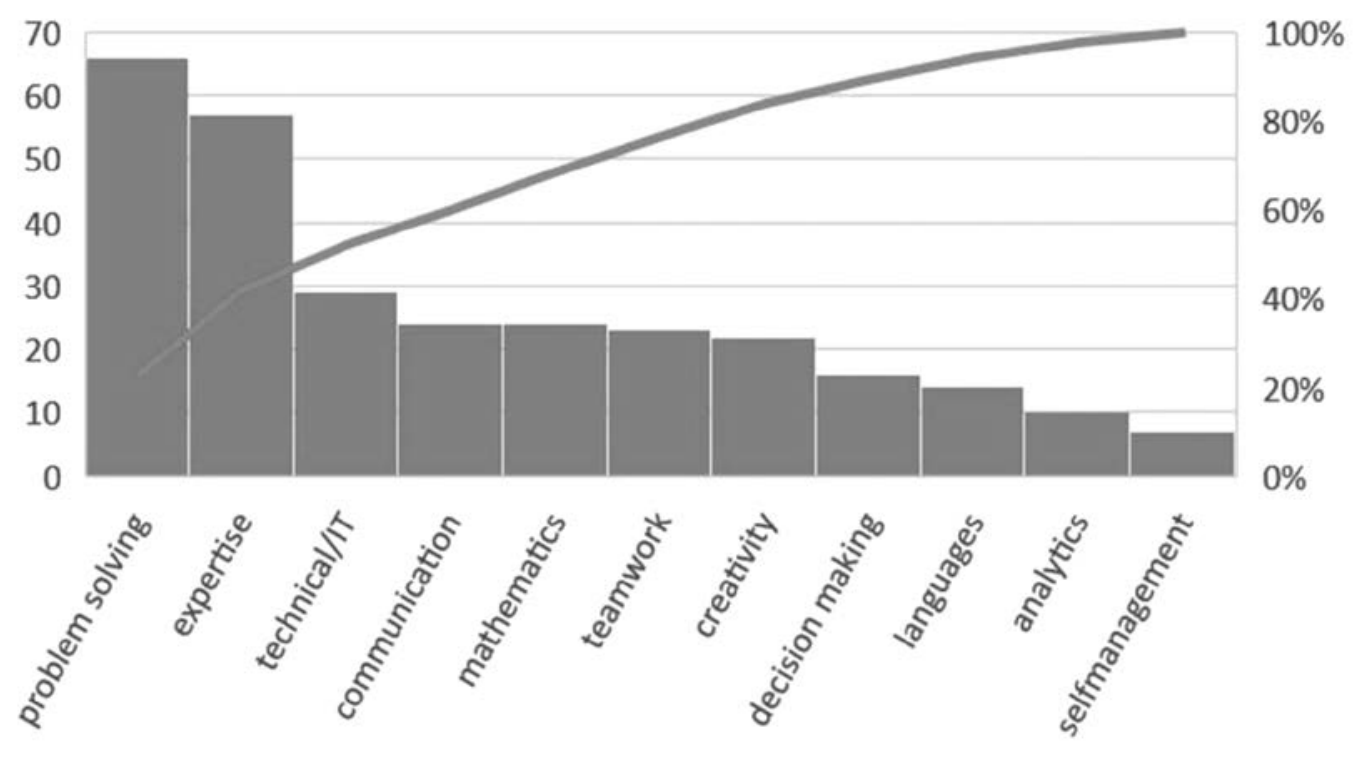

Source: Authors' own survey

\section{Future Research and Limitation}

We are seeking to extend our research to students from the business and economic faculty at our university to compare how their responses with the present competencies. Furthermore, we seek to have the engineering students enrolled this year to retake the same test next year to see if time has influenced their views on the same topics (Takács-György \& Takács, 2017). We also are planning to have an English version of our questionnaire available to ask students with very similar, if not the same curricula abroad, to take the text to sample international trends and attitudes, as well.

The research has several limitations. First, the companies who were interviewed, are not representative of the entire car industry in Hungary, as more SMEs and larger entities could reshape the competence list and order. International companies not only do not have the same profile, but they differ in income, trade, and manufacturing methods as well, which means that the listed order of competency cannot be generalized for the entire car industry, even here in Hungary. The study has not queried any purely foreign entities residing in Hungary as well, nor has it queried any Hungarian businesses working abroad in the same field, that offer opportunities for future employees.

\section{Conclusion}

As educators, we believe in the power of education. Universities need to rethink how basic research, education, and other services are transforming applied research, curricula, and practices into real solutions (Dobbins \& Knill, 2009). Universities have been the depositaries of science for hundreds of years and have been skills, active participation in teamwork, problem-solving, and creative approaches are necessary for this new, interconnected, and innovation-driven environment using group assignments, but also encouraging verbal and written self-expression. As of 2018, Óbuda University, Bánki Faculty has introduced two new subjects into their curriculum: Project and Teamwork and Project Management. These are offered in English and the first step for students is to form groups of students who together will present a chosen project at the end of each semester (Oberst, Gallifa \& Farriols, 2009). Effective communication modules and problem-solving cases are also being offered to better prepare our students for future employment. (Beke \& Kolnhofer-Derecskei, 2018).

Higher education is trying to adapt to new norms by reforming its educational structure, increasing the use of digitized textbooks, and providing non-place-based learning 
modules (Pepper, 2011). In line with industry expectations, the introduction of new subjects such as robotics or cybersecurity, in addition to the old ones, is as essential as studying abroad, working in teams or developing international projects, as is joining or forming research hubs or inviting foreign universities to cooperate.

Together, with support from higher education institutions, industry and governments can assist in these processes for training students that best meet the demands of the newest labor market trends.

\section{Acknowledgments}

Supported by the ÚNKP-19-1415/38 New National Excellence Program of the Ministry for Innovation and Technology.

\section{References}

Andrasko, B., \& Baracskai, Z. (2020). Scenarios evaluation of future workplaces. Economic and Social Development: Book of Proceedings, 327-338.

Aryal, A., Becerik-Gerber, B., Anselmo, F., Roll, S. C., \& Lucas, G. (2019). Smart desks to promote comfort health and productivity in offices: A vision for future workplaces. Frontiers in Built Environment, 5, 76. https://doi.org/10.3389/fbuil.2019.00076

Ariss, A.A., Cascio W.F., \& Paauwe, J., (2014). Talent management: Current theories and future research directions. Journal of World Business, 49(2),173-179. https://doi.org/10.1016/j.jwb.2013.11.001

Beke É., \& Kolnhofer-Derecskei A. (2018): Talent management at Óbuda University focusing on teachers' and students' roles. Konferenciaközlemény (FIKUSZ). Retrieved from http://kgk.uni-obuda.hu/sites/default/files/FIKUSZ2018_05.pdf

Beke É. (2018): Industry 4.0 and its risks in the state administration, corporate, and medical sectors. National Security Review: Periodical of the Military National Security Service (1) 98-110.

Bencsik, A., Horváth-Csikós, G., \& Juhász, T. (2016). Y and Z generations at workplaces. Journal of Competitiveness, 8(3). https://doi. org/10.7441/joc.2016.03.06

Benesova, A. - Tupa J. (2017): Requirements for education and qualification of people in Industry 4.0. Procedia Manufacturing, 11(2), 195-220 https://doi.org/10.1016/j.promfg.2017.07.366

Bevan, S., Brinkley, I., Cooper, C., \& Bajorek, Z. (2018). 21st Century Workforces and Workplaces: The Challenges and Opportunities for Future Work Practices and Labour Markets. Bloomsbury Publishing.

Birkner, Z., Máhr, T., Péter, E., \& Rodek Berkes, N. (2018). Characteristics of innovation in regions with small and medium-sized Towns. Naše Gospodarstvo/Our Economy, 64(2), 34-42. https://doi.org/10.2478/ngoe-2018-0010

Byström, K., Ruthven, I. \& Heinström, J. (2017). Work and information: Which workplace models still work in modern digital workplaces? Information Research, 22(1), CoLIS paper 1651.

Črešnar, R., \& Jevšenak, S. (2019). The Millennials' effect: How can their personal values shape the future business environment of industry 4.0? Naše Gospodarstvo/Our Economy, 65(1), 57-65. https://doi.org/10.2478/ngoe-2019-0005

Cséfalvay Z. (2017). A nagy korszakváltás. Kairosz Kiadó, Budapest, Hungary.

Dobbins, M., \& Knill, C. (2009). Higher education policies in Central and Eastern Europe: Convergence toward a common model. Governance, 22(3), 397-430. https://doi.org/10.1111/j.1468-0491.2009.01445.x

Erol, S., Jäger, A., Hold, P., Ott, K., \& Sihn, W. (2016). Tangible Industry 4.0: A scenario-based approach to learning for the future of production. Procedia CiRp, 54, 13-18. https://doi.org/10.1016/j.procir.2016.03.162

Hood, C., \& Nanda, A. (2018). What could work for future workplaces, beyond working? Corporate Real Estate Journal, 7(4), $352-368$.

Gunnarsson, B. L. (2014). Multilingualism in European workplaces. Multilingua, 33(1-2), 11-33. https://doi.org/10.1515/ multi-2014-0002

Michalos, G., Makris, S., Tsarouchi, P., Guasch, T., Kontovrakis, D., \& Chryssolouris, G. (2015). Design considerations for safe human-robot collaborative workplaces. Procedia CIrP, 37, 248-253. https://doi.org/10.1016/j.procir.2015.08.014

Miller, M. P., \& Marsh, M. E. (2014). The Digital Renaissance of Work: Delivering Digital Workplaces Fit for the Future. Gower Publishing, Ltd. Mohle, B. (2012). High-performance workplaces of the future. The Queensland Nurse, 1(1), 3.

Mulder, M. (2014). Conception of professional competence S. Billett, C. Harteis, H. Gruber (Eds). International Handbook of Research in Professional and Practice-based Learning. Dordrecht: Springer, 107-137. https://doi.org/10.1007/978-94-017-8902-8_5

Oberst, U., Gallifa, J., \& Farriols, N. (2009). Training emotional and social competencies in higher education: The seminar methodology. Journal Higher Education in Europe 34(3-4). https://doi.org/10.1080/03797720903392243

Oosthuizen, R. M. (2019). Smart technology, artificial intelligence, robotics, and algorithms (STARA): Employees' perceptions and wellbeing in future workplaces. Theory, Research and Dynamics of Career Wellbeing, 17-40. Springer, Cham. https://doi. org/10.1007/978-3-030-28180-9_2 
Pepper, D. (2011). Assessing key competencies across the curriculum-and Europe, European Journal of Education. https://doi. org/10.1111/j.1465-3435.2011.01484.x

Portera, A., \& Grant, C. (2017). Intercultural education and competencies: Challenges and answers for the global world. Cambridge Scholars Publishing.

Salovaara, P. (2015). What Can the Coworking Movement Tell Us about the Future of Workplaces? Leadership in Spaces and Places. Edward Elgar Publishing. https://doi.org/10.4337/9781783477920.00008

Schwab, K. (2017). The Fourth Industrial Revolution. Crown Business.

Schwartz, J., Hatfield, S., Jones, R., \& Anderson, S. (2019). What is the future of work: Redefining work, workforces, and workplaces. Part Of A Deloitte Series On The Future Of Work.

Simic, M., \& Nedelko, Z. (2019). Development of competence model for Industry 4.0: A theoretical approach. 37th International Scientific Conference on Economic and Social Development: Book of Proceedings, 1289-1299. https://www.esd-conference.com/ past-conferences

Szalavetz A., (2018). Ipari fejlődés és munka a tudásalapú társadalomban. Magyar Tudomány (1). https://doi. org/10.1556/2065.179.2018.1.6

Takács-György, K. \& Takács, I. (2017). Talent management in higher education: A case study from Hungary. International Journal of Contemporary Management, 16(3), 157-188. https://doi.org/10.4467/24498939IJCM.17.027.7547

Wagenaar, R. (2014). Competences and learning outcomes: a panacea for understanding the (new) role of higher education? Tuning Journal for Higher Education, 1, 279-302. https://doi.org/10.18543/tjhe-1(2)-2014pp279-302

\section{Industrija 4.0 in trenutne kompetence}

\section{Izvleček}

Vrzel med visokošolskimi sistemi in potrebami ter povpraševanjem na trgih dela je vedno večja. Mnogi današnji študentje bodo delali na delovnih mestih nove vrste, ki so se šele začela oblikovati ali sploh še ne obstajajo. Zaradi tega bodoči delavci v naslednjih letih potrebujejo tako digitalne kot socialno-čustvene veščine. Ta nova usposobljenost bo omogočala, da bo zaposleni uspešen na delovnem mestu, kjer bo moral za doseganje ciljev podjetja sodelovati v skupinah - tudi z različnimi generacijami. Namen tega prispevka je predstaviti rezultate raziskave o sodobni usposobljenosti, ki proučuje dva vidika: na eni strani ugotavlja, kakšna so pričakovanja zadevnih podjetij, na drugi strani pa, kako študentje vidijo svoje znanje in vrednost na prihodnjih delovnih mestih ter kako se z novo zahtevo spopadajo akademski krogi. Za to analizo smo opravili poglobljene pogovore z ustreznimi subjekti in na osnovi vprašalnika pridobili mnenja inženirstva na Univerzi Óbuda. Na podlagi njihovih odgovorov in nadaljnjih raziskav si prizadevamo, da bi vključili mednarodna podjetja, ki bi temeljiteje sodelovala z našim visokošolskim sistemom bodisi s širitvijo praktičnega izobraževanja na kraju samem bodisi s povabilom na našo univerzo za predavanje prihodnjim inženirjem.

Ključne besede: zmožnosti industrije 4.0, univerzitetna izobrazba, prihodnji učni načrti 